\section{Pengembangan Biomagz sebagai Sumber Belajar Biologi Siswa SMA}

\author{
Gregorian Trijulensius \\ Mushawwir Taiyeb \\ Andi Asmawati Azis
}

\begin{abstract}
Abstrak. Penelitian ini bertujuan untuk menghasilkan produk BioMagz sebagai alternative sumber belajar mandiri yang valid dan praktis digunakan di SMA Negeri 1 Mangkutana. Penelitian ini merupakan penelitian pengembangan dengan menggunakan model 4D oleh Thiagarajan yang terdiri dari 4 langkah, yaitu (1) Define (Pendefenisisan), (2) Design (Perancangan), (3) Develop (Pengembangan) dan Disseminate (Penyebaran). Hasil penelitian BioMagz yang dikembangkan bersifat valid dan praktis. Nilai kevalidan adalah 4,17 yang berarti bahwa BioMagz sebagai alternatif sumber belajar mandiri termasuk dalam kriteria valid. Nilai kepraktisan adalah 4,6 yang berarti bahwa BioMagz sebagai alternatif sumber belajar mandiri tergolong dalam kriteria praktis. Persentasi Hasil respons siswa terhadap siswa yaitu 84,5\% yang berarti siswa memberikan respon positif terhadap BioMagz.

Kata Kunci: BioMagz, Alternatif, Sumber Belajar Mandiri
\end{abstract}

\section{Pendahuluan}

Pendidikan merupakan posisi yang strategis dalam meningkatkan kualitas Sumber Daya Manusia (SDM), baik dalam aspek spiritual, intelektual maupun kemampuan profesional terutama dikaitkan dengan tuntutan pembangunan bangsa (Titadewi, 2013). Kualitas pendidikan saat ini memang masih menjadi satu permasalahan yang sangat serius dalam usaha perbaikan mutu sistem pendidikan nasional. Berbagai upaya telah dilakukan untuk mengatasi masalah pendidikan. Pembelajaran di kelas dipengaruhi oleh beberapa faktor yang berasal dari dalam dan faktor dari luar. Dengan demikian perlu adanya pengembangan terhadap faktorfaktor tersebut sehingga tercapai hasil belajar yang maksimal. Faktor-faktor yang berasal dari dalam diri siswa diantaranya minat, bakat, motivasi dan wawasan. Wawasan sangat diperlukan dalam proses belajar mengajar karena dengan adannya wawasan yang luas akan menumbuhkan minat dan perhatian siswa dalam proses belajar mengajar. Peningkatan wawasan siswa tak lepas dari pengaruh buku sebagai sumber belajar siswa. (Yulianto, 2010). Menurut permendiknas RI no.2 Th 2008 pasal 1 ayat 3, menjelaskan bahwa buku pendidikan bertujuan memberikan pengalaman, pengetahuan, ketrampilan, kepada siswa tentang kehidupan dalam berbagai bidangnya, baik tentang duania, masyarakat dan alam sekitarnya maupun tentang Tuhan Yang Maha Esa. Hal ini menandakan bahwa buku sangatlah penting dalam meningkatkan wawasan siswa serta keberhasilan siswa dalam kegiatan pembelajaran

\section{Biology Teaching and Learning}

p-ISSN 2621 - 5527

e-ISSN 2621 - 5535

Abstract. This research was aimed to produce BioMagz product as an alternative resource of independent learning which was valid and practical used in SMA Negeri 1 Mangkutana. This was a research and development using 4D model by Thiagarajan which consisted of 4 steps, namely (1) Define,

(2) Design, (3) Develop and Disseminate. The research result developed BioMagz was valid and practical. The value of the validity was 4.17 which meant that BioMagz as an alternative resource of independent learning included in the valid criteria. The value of practicality was 4.6 , which meant that BioMagz as an alternative resource of independent learning belonged to the practical criteria. While the student response presentation of 84,5\% which means BioMagz got positive response from student. Keywords: BioMagz, Alternative, Resource of Independent Learning

Gregorian Trijulensius Universitas Negeri Makassar Indonesia

Mushawwir Taiyeb Universitas Negeri Makassar Indonesia

Andi Asmawati Azis Universitas Negeri Makassar Indonesia 
sebagaimana tujuan dari pendidikan.

Majalah biologi adalah salah satu sumber belajar yang dapat dimanfaatkan dalam proses belajar mengajar karena isi majalah yang menarik, dan banyak menggunakan gambar. Hal ini sesuai dengan Trianto (2010) yang mengatakan keberhasilan pembelajaran sangat bergantung pada penggunaan maupun media belajar yang dipilih. Sumber belajar dan bahan ajar yang sesuai dapat memenuhi tujuan pembelajaran, yaitu memotivasi menarik perhatian dan menstimulasi siswa melalui materi pembelajaran.

BioMagz adalah salah satu media yang dapat digunakan sebagai alat untuk memahami materi biologi, sekaligus dapat memberikan kesenagan dalam belajar biologi. Sebagai sumber belajar mandiri. Menurut Willian (dalam Aritonang, 2009), minat belajar merupakan ketertarikan siswa terhadap pembelajaran sebagai faktor yang menentukan derajat keaktifan belajar siswa.

Kurikulum Tingkat Satuan Pendidikan (KTSP), menjelaskan bahwa pembelajaran siswa diarahkan kepada pembelajaran mandiri. Menurut Mudjiman (2008) " belajar mandiri adalah kegiatan belajar aktif, yang didorong oleh niat atau motif untuk menguasai sesuatu kompetensi guna mengatasi suatu masalah dan dibangun dengan bekal pengetahuan atau kompetensi yang telah dimiliki". Maka untuk menimbulkan kegiatan pembelajaran yang aktif dan mandiri, diperlukan perangkat pembelajaran yang mendukung proses belajar mandiri sangat diperlukan, baik berupa bahan ajar, sumber belajar maupun media belajar.. BioMagz menjadi alternatif yang sesuai sebagai sumber belajar mandiri bagi siswa.

Menururt Ali (2009), majalah biologi (BioMagz) sebagai sumber belajar memiliki beberapa kelebihan yakni : 1) siswa dapat belajar dan maju sesuai dengan kecepatan masingmasing. Meskipun pada akhirnya semua siswa diharapkan dapat menguasai topik yang disajikan, 2) siswa akan mengikuti urutan pikiran secara logis melalui pengulangan materi antara yang dijelaskan guru dan bacaan dalam Biomagz 3) perpaduan teks dan gambar dapat menambah daya tarik dan memperlancar pemahaman informasi yang disajikan dalam dua format, verbal dan visual, 4) berisi informasi yang bersifat aplikatif sesuai dengan perkembangan dan temuantemuan baru, sehingga dapat dijadikan suplemen pembelajaran siswa.

Berdasarkan uraian di atas maka peneliti melalukan penelitian dengan judul "Pengembangan BioMagz sebagai alternatif Sumber Belajar Mandiri pada Mata Pelajaran Biologi untuk Siswa SMA".

\section{Metode Penelitian}

\section{Jenis dan Desain Penelitian}

Penelitian ini merupakan Research and Development (R \& D) dengan menggunakan model 4D oleh Thiagarajan yang terdiri dari 4 langkah, yaitu (1) Define (Pendefenisisan), (2) Design (Perancangan), (3) Develop (Pengembangan) dan Disseminate (Penyebaran), namun tahap disseminate tidak dilakukan karena adanya keterbatasan waktu dan dana yang membatasi penelitian.

\section{Tempat dan Waktu Penelitian}

Penelitian ini telah dilaksanakan pada bulan Februari- Mei di Jurusan Biologi Universitas Negeri Makassar dan akan diuji kepraktisan pada SMAN di Mangkutana.

Subjek Penelitian

Subjek dalam penelitian pengembangan adalah media Biomagz yaitu majalah biologi dengan responden guru Biologi SMAN di Mangkutana

Prosedur Penelitian

Penelitian ini menggunakan model 4D dengan tahap penelitian sebagai berikut :

a. Define (Pendefinisian) 
Kegiatan pada tahap ini dilakukan untuk menetapkan dan mendefinisikan syarat-syarat pengembangan.

b. Design (Perancangan)

Pada konteks pengembangan bahan ajar, tahap ini dilakukan untuk membuat majalah BioMagz dengan kerangka isi hasil analisis kurikulum dan materi sesuai dengan tujuan yang telah dirumuskan. Sebelum rancangan (design) produk dilanjutkan ke tahap berikutnya, maka rancangan produk (BioMagz) tersebut kemudian diperiksa oleh dosen pembimbing.

1. Memilih dan menetapkan spesifikasi software, hardware dan perangkat pembelajaran.

Pengembangan BioMagz pada materi Sistem Pencernaan membutuhkan sumber informasi sebagai panduan dalam mengembangkannya. Sumber tersebut yaitu buku biologi SMA kelas XI kurikulum 2006, silabus SMA kelas XI IPA, buku Campbell biologi serta jurnal penelitian yang mendukung materi dalam pengembangan BioMagz, Sofware yang digunakan untuk mengembangkan BioMagz yaitu Adobe Photoshop, Adobe InDesign CS6 dan Ms. Word

\section{Instrumen Penelitian}

Instrument penelitian yang dibuat meliputi lembar validasi materi dan media oleh dosen ahli beserta rubrik penilaiannya dan lembar kepraktisan oleh guru SMA.

c. Develop (Pengembangan)

Thiagarajan membagi tahap pengembangan dalam dua kegiatan yaitu: expert appraisal dan developmental testing. Expert appraisal merupakan teknik untuk memvalidasi atau menilai kelayakan rancangan produk. Dalam kegiatan ini dilakukan evaluasi oleh ahli dalam bidangnya. Instrumen Penelitian

Keseluruhan instrumen akan divalidasi oleh empat validator yaitu dua orang sebagai validator ahli dan dua orang bertindak sebagai validator praktisi (guru). Instrumen pengumpulan data yang digunakan pada penelitian ini adalah sebagai berikut:

1) Lembar validasi perangkat pembelajaran

Lembar validasi ini adalah lembar yang dibuat oleh peneliti dan diberikan kepada validator untuk menvalidasi angket dan Biomagz. Tujuan validasi ini adalah untuk mendapatkan suatu kevalidan dan kepraktisan perangkat pembelajaran.

2) Lembar praktisi perangkat pembelajaran

Lembar praktisi ini adalah lembar yang dibuat oleh peneliti dan diberikan kepada praktisi (guru IPA) untuk menilai tingkat kepraktisan Biomagz

Teknik Pengumpulan Data

Teknik pengumpulan data merupakan cara memperoleh data atau informasi dari responden dengan menggunakan instrumen penelitian. Instrumen penelitian yang digunakan adalah kuesioner atau angket.

a. Kevalidan

Menurut Hobri (2009), berdasarkan data hasil penilaian kevalidan media pembelajaran dari beberapa ahli ditentukan rata-rata nilai indikator yang diberikan masing-masing validator. Aspek-aspek yang dinilai oleh validator antara lain: kesesuaian perangkat dengan Standar Kompetensi, Kompetensi Dasar, Indikator, keakuratan materi-materi, materi pendukung pembelajaran, teknik penyajian perangkat pembelajaran, dan kelengkapan penyajian perangkat pembelajaran.

b. Kepraktisan

Media pembelajaran yang dikembangkan dalam penelitian ini dikatakan praktis apabila telah mencapai rata-rata tingkat kepraktisan di atas $80 \%$.

Teknik Analisis Data

1. Teknik mengukur kevalidan media oleh para ahli

Menurut Hobri (2009), berdasarkan data hasil penilaian kevalidan media dari beberapa ahli yang kompeten dalam bidang pengembangan media ditentukan rata-rata nilai indikator yang diberikan masing-masing validator. 
Melakukan rekapitulasi data penilaian kevalidan media ke dalam tabel yang meliputi: aspek (Ai), indikator (Ii), dan nilai (Vji) untuk masing-masing validator yang meliputi validator ahli media, ahli materi atau isi mata pelajaran.

1. Menentukan rata-rata nilai hasil validasi dari semua validator untuk setiap indikator dengan rumus:

$I i=\frac{\sum_{j=1}^{n} V j i}{n}$

dimana,

Ii = rerata untuk aspek ke- $i$ indikator ke- $j$,

Vji= data nilai validator ke- $j$ terhadap indikator ke- $i$,

$\mathrm{n}$ = adalah banyaknya validator

hasil yang diperoleh kemudian ditulis pada kolom dalam tabel yang sesuai.

2. Menentukan rerata nilai untuk setiap aspek dengan rumus:

$A i=\frac{\sum_{j=1}^{n} I i f}{m}$

dimana,

$A i=$ rerata nilai untuk aspek ke- $i$,

Iij = rerata untuk aspek kei-i indikator ke- $j$,

$\mathrm{m}$ = banyaknya indikator dalam aspek ke- $i$

hasil yang diperoleh kemudian ditulis pada kolom dalam tabel yang sesuai.

3. Menentukan nilai Va atau nilai rerata total dari rerata nilai untuk semua aspek dengan rumus:

$V a=\frac{\sum_{i=1}^{n} A i}{n}$

dimana,

$\mathrm{Va} \quad=$ nilai rerata total untuk semua aspek,

$\mathrm{Ai} \quad=$ rerata nilai untuk aspek ke- $i$,

$n \quad$ = banyaknya aspek

hasil yang diperoleh kemudian ditulis pada kolom dalam tabel yang sesuai.

Selanjutnya nilai Va atau nilai rata-rata total ini dirujuk pada interval penentuan tingkat kevalidan BioMagz dapat dilihat pada tabel 3.1 berikut.

Tabel 1. Interval Penentuan Tingkat Kevalidan Produk

\begin{tabular}{|c|c|}
\hline Interval skor & Kategori Kevalidan \\
\hline $1 \leq \mathrm{Va}<2$ & tidak valid \\
\hline $2 \leq \mathrm{Va}<3$ & kurang valid \\
\hline $3 \leq \mathrm{Va}<4$ & cukup valid \\
\hline $4 \leq \mathrm{Va}<5$ & Valid \\
\hline $\mathrm{Va}=5$ & sangat valid \\
\hline
\end{tabular}

Kriteria menyatakan media memiliki derajat validitas yang baik, jika minimal tingkat validitas yang dicapai adalah tingkat valid. Jika tingkat pencapaian validitas di bawah valid, maka perlu dilakukan revisi berdasarkan masukan (koreksi) validator. Selanjutnya dilakukan kembali validasi. Demikian seterusnya sampai diperoleh media yang valid (Hobri, 2009).

2. Teknik mengukur kepraktisan media oleh para ahli dan para praktisi

Teknik analisa yang sama untuk mengukur kevalidan juga dilakukan pada penilaian tentang kepraktisan atau keterlaksanaan oleh praktisi (guru Biologi) terhadap media berdasarkan persepsi dan pengalamannya, namun nilai rata-ratanya atau IP dirujuk pada interval kepraktisan media sebagai berikut: 
Tabel 2. Kriteria Pengkategorian Kepraktisan Biomagz

\begin{tabular}{|c|c|}
\hline Interval skor & Kategori Kepraktisan \\
\hline $1 \leq \mathrm{IP}<2$ & Sangat tidak baik \\
\hline $2 \leq \mathrm{IP}<3$ & Tidak baik \\
\hline $3 \leq \mathrm{IP}<4$ & Kurang baik \\
\hline $4 \leq \mathrm{IP}<5$ & Baik \\
\hline $\mathrm{IP}=5$ & Sangat baik \\
\hline
\end{tabular}

\section{Hasil dan Pembahasan}

Penelitian pengembangan yang telah dilakukan mengacu pada model pengembangan 4-D. Adapun hasil dari tahapan pelaksanaan penelitian sebagai berikut.

1. Define (Pendefenisisan)

Hasil dari tahap pendefinisian Biomagz adalah sebagai berikut :

a. Analisis Kurikulum

Kurikulum yang saat ini banyak digunakan di SMA di daerah yaitu kurikulum KTSP Tahun 2006. Jadi media yang dikembangkan disesuaikan dengan kurikulum KTSP Tahun 2006.

Tabel 3. Analisis kurikulum

\begin{tabular}{|c|l|l|}
\hline SK & \multicolumn{1}{|c|}{ Standar Kompotensi } & \multicolumn{1}{c|}{ Kompetensi Dasar } \\
\hline 3 & $\begin{array}{l}\text { Menjelaskan struktur dan fungsi } \\
\text { organ manusia dan hewan tertentu, } \\
\text { kelainan/penyakit yang mungkin } \\
\text { terjadi serta implikasinya pada } \\
\text { Salingtemas }\end{array}$ & $\begin{array}{l}\text { 3.3 Menjelaskan keterkaitan antara } \\
\text { struktur, fungsi, dan proses serta kelainan } \\
\text { penyakit yang dapat terjadi pada sistem } \\
\text { pencernaan makanan pada manusia }\end{array}$ \\
\hline
\end{tabular}

b. Analisis karakteristik peseta didik

Tahapan ini dilakukan dengan tujuan untuk menyesuaikan karakter siswa yang akan menggunakan media tersebut dengan Biomagz. Beberapa siswa mengaku kesulitan untuk mencari bahan bacaan saat masuk perpustakaan sedangkan mereka tidak mempunyai akses untuk internet disekolah jadi untuk mencari informasi tujuan utama mereka adalah perpustakaan. Untuk membeli buku paket juga mereka kesulitan dikarenakan penghasilan orang tua yang tidak memcukupi.

Dalam pergaulan sehari-hari siswa disekolah mereka lebih banyak menggunakan bahasa Indonesia, kegiatan pembelajaran dikelas juga guru lebih mengutamakan penggunaan bahasa Indonesia.

\section{c. Analisis Materi}

Analisis karakteristik materi dilakukan untuk mengetahui konsep dalam merancang media pembelajaran. Sesuai observasi pada SMA Negeri 1 Mangkutana masih menerapkan KTSP pada sistem pembelajaran di kelas XI IPA.. Kompetensi Dasar (KD) 3.3 "menjelaskan keterkaitan antara struktur, fungsi, dan proses serta kelainan penyakit yang dapat terjadi pada sistem pencernaan makanan pada manusia"

Secara umum materi yang dikembangkan yaitu struktur dan fungsi sistem pencernaan, serta penyakit dan pencegahannya pada sistem pencernaan manusia. Secara rinci dapat dilihat Tabel 4. 
Tabel 4. Rincian Konten Materi Sistem Pencernaan Manusia

\begin{tabular}{|l|l|l|}
\hline No & \multicolumn{1}{|c|}{ Konten Materi } & \multicolumn{1}{c|}{ Penjelasan } \\
\hline 1 & Sistem pencernaan manusia & $\begin{array}{l}\text { Pada materi ini diceritakan mengenai pengertian } \\
\text { susunan organ pencernaan manusia dan pentingnya } \\
\text { menjaga sistem pencernaan. }\end{array}$ \\
\hline 2 & Saluran Pencernaan Manusia & $\begin{array}{l}\text { Materi ini menjelaskan organ-organ yang masuk } \\
\text { dalam tipe saluran pencernaan( Mulut, (gigi, lidah } \\
\text { kelenjar saliva), keronkongan, lambung, usus halus, } \\
\text { usus besar, anus dan rektum). Dituliskan pula } \\
\text { beberapa kelainan yang dapat menyerang saluran } \\
\text { pencernaan. Terdapat juga beberapa tips untuk } \\
\text { menjaga kesehatan organ pencernaan. }\end{array}$ \\
\hline 3 & $\begin{array}{l}\text { Kelenjar Pencernaan } \\
\text { Manusia }\end{array}$ & $\begin{array}{l}\text { Materi ini menjelaskan kelenjar yang berperan } \\
\text { dalam pencernaan manusia, yaitu organ hati dan } \\
\text { pancreas. }\end{array}$ \\
\hline 4 & Zat Makanan & $\begin{array}{l}\text { Materi ini menjelaskan mengenai kandungan zat } \\
\text { yang terkandung dalam makanan dan minuman yang } \\
\text { sehat. Yang masuk dalam kandungan zat makanan } \\
\text { yaitu protein, karbohidrat, lemak(lipid), vitamin, } \\
\text { mineral, dan air }\end{array}$ \\
\hline 5 & $\begin{array}{l}\text { Sistem Pencernaan pada } \\
\text { hewan ruminansia }\end{array}$ & $\begin{array}{l}\text { Materi ini menjelaskan mengenai perbedaan sistem } \\
\text { percernaan pada hewan ruminansia. }\end{array}$ \\
\hline 6 & Kamus Biologi & $\begin{array}{l}\text { Istilah penting yang sering digunakan dalam sistem } \\
\text { pencernaan. }\end{array}$ \\
\hline
\end{tabular}

d. Merumuskan Tujuan

Perumusan tujuan pembelajaran disesuaikan dengan standar kompetensi dan kompetensi dasar dalam pembelajaran.

2. Design (Perancangan)

Tahap ini bertujuan untuk menghasilkan bentuk akhir produk yang dikembangkan pada tahap perencanaan. Setelah dilakukan pembuatan produk, dalam hal ini BioMagz maka dilakukan tahap-tahap berikut :

1. Memilih dan Menetapkan Spesifikasi Software, Hardware dan Perangkat Pembelajaran.

Berikut perangkat dan spesifikasi yang digunakan yaitu dapat dilihat tabel 5 .

Tabel 5. Spesifikasi Software, Hardware dan Perangkat Pembelajaran

\begin{tabular}{|l|l|}
\hline \multicolumn{1}{|c|}{ Jenis } & Nama Bahan yang Dikumpulkan \\
\hline Perangkat Keras (Hardware) & Laptop/Notebook \\
\hline Perangkat Lunak (Software) & $\begin{array}{l}\text { Photoshop } \\
\text { Adobe Indesign CS6 } \\
\text { Ms.Word }\end{array}$ \\
\hline Perangkat Pembelajaran & Silabus biologi SMA kelas XI \\
& Campbell jilid 8 \\
& Buku paket biologi SMA kelas XI, \\
& BSE SMA kelas XI \\
& Internet \\
\hline
\end{tabular}

Pembuatan Perencanaan Rancangan

Desain perencanaan pengembangan pelaksanaan pengembangan dan sebagai kontrol dalam proses pengembangan. 


\section{Tahap Pengembangan (Develop)}

Data yang diperoleh dalam penelitian pengembangan BioMagz ini terdiri dari data hasil evaluasi produk untuk menguji kevalidan BioMagz dan data hasil angket respon guru untuk menguji kepraktisan BioMagz serta hasil respon siswa untuk menguji keefektifan produk.

2. Data hasil evaluasi produk

Data hasil uji evaluasi produk meliputi data hasil evaluasi produk dari dua dosen ahli. Data evaluasi ini meliputi penilaian aspek kejelasan objek, kualitas gambar, warna teks, ukuran teks dan keterbacaan media yang dikonversikan dalam empat kategori yaitu sangat valid, valid, kurang valid dan tidak valid.

1. Analisis Data Kevalidan

a. Aspek Format Biomagz

Adapun hasil validasi untuk aspek format petunjuk Biomagz dapat dilihat pada tabel 6 berikut:

Tabel 6. Aspek Format Biomagz

\begin{tabular}{|c|c|c|c|}
\hline No & Komponen yang ditelaah & Dosen 1 & Dosen 2 \\
\hline 1 & Ukuran huruf pada sumber belajar Biomagz & 5 & 5 \\
\hline 2 & Variasi jenis huruf pada sumber belajar Biomagz & 5 & 5 \\
\hline 3 & Keterbacaan teks pada sumber belajar Biomagz & 5 & 5 \\
\hline 4 & Kualitas gambar pada sumber belajar Biomagz & 3 & 4 \\
\hline 5 & $\begin{array}{l}\text { Keserasian pemilihan warna background dengan teks } \\
\text { dan gamb }\end{array}$ & 3 & 4 \\
\hline 6 & $\begin{array}{l}\text { Ketepatan penempatan gambar sumber belajar } \\
\text { Biomagz }\end{array}$ & 3 & 4 \\
\hline 7 & Ketepatan layout pengetikan sumber belajar Biomagz & 3 & 4 \\
\hline 8 & $\begin{array}{l}\text { Ketepatan penempatan judul dan subjudul pada } \\
\text { Biomagz }\end{array}$ & 4 & 4 \\
\hline 9 & $\begin{array}{l}\text { Konsistensi Pengunaan sistem penomoran pada } \\
\text { Biomagz }\end{array}$ & 4 & 5 \\
\hline 10 & Kesesuaian pengorganisasian isi Biomagz & 3 & 4 \\
\hline & Jumlah & 38 & 44 \\
\hline & $I i=\frac{\sum_{j=1}^{n} V j i}{n}$ & \multicolumn{2}{|c|}{41} \\
\hline & $A i=\frac{\sum_{j=1}^{n} I i f}{m}$ & \multicolumn{2}{|c|}{$4,1 /$ Valid } \\
\hline
\end{tabular}

b. $\quad$ Aspek Isi Biomagz

Adapun hasil validasi untuk aspek isi Biomagz dapat dilihat pada tabel 7 berikut: 
Tabel 7. Aspek Isi Biomagz

\begin{tabular}{|l|l|c|c|}
\hline No & \multicolumn{1}{|c|}{ Komponen yang ditelaah } & Dosen 1 & Dosen 2 \\
\hline 1 & $\begin{array}{l}\text { Kesesuaian materi (Sistem Pencernaan ) dengan } \\
\text { Standar Kompetensi }\end{array}$ & 4 & 5 \\
\hline 2 & Kebenaran materi (Sistem Pencernaan) yang disajiakn & 4 & 4 \\
\hline 3 & $\begin{array}{l}\text { Penyajian Materi (Sistem Pencernaan) secara } \\
\text { berurutan dan sistematik }\end{array}$ & 5 & 4 \\
\hline 4 & Kejelasan uraian Materi Sistem Pencernaan & 4 & 4 \\
\hline 5 & Keseuaian gambar yang disajikan pada submateri & 4 & 4 \\
\hline & Jumlah & 21 & 21 \\
\hline & \multicolumn{1}{|c|}{$4 i=\frac{\sum_{j=1}^{n} V j i}{n}$} & 21 \\
\hline & $A i=\frac{\sum_{j=1}^{n} I i f}{m}$ & \multicolumn{2}{|c|}{} \\
\hline
\end{tabular}

c. Aspek Bahasa

Tabel 8. Aspek Bahasa Biomagz

\begin{tabular}{|l|l|c|c|}
\hline No & Komponen yang ditelaah & Dosen 1 & Dosen 2 \\
\hline 1 & $\begin{array}{l}\text { Kesesuaian bahasa dengan tingkat } \\
\text { berpikir siswa }\end{array}$ & 5 & 4 \\
\hline 2 & Kelugasan Bahasa pada Biomagz & 3 & 4 \\
\hline 3 & $\begin{array}{l}\text { Ketepatan penggunaan istilah, tata } \\
\text { bahasa dan ejaan yang digunakan }\end{array}$ & 3 & 4 \\
\hline 4 & $\begin{array}{l}\text { Bahasa yang digunakan } \\
\text { membangkitkan rasa ingin tahu } \\
\text { siswa }\end{array}$ & 3 & 4 \\
\hline & Jumlah $I i=\frac{\sum_{j=1}^{n} \text { Vji }}{n}$ & 14 & 16 \\
\hline & \multicolumn{2}{|c|}{15} \\
\hline & $A i=\frac{\sum_{j=1}^{n} \text { Iif }}{m}$ & $3,75 /$ Valid \\
\hline
\end{tabular}

Setelah mendapatkan hasil validasi dari setiap aspek Biomagz dapat dirumuskan ratarata total tiap aspek tersebut dan dapat dilihat pada Tabel 9 berikut:

Tabel 9. Hasil Validasi untuk Semua Aspek

\begin{tabular}{|l|l|c|c|}
\hline \multirow{2}{*}{ No } & \multicolumn{1}{|c|}{ Aspek } & $\begin{array}{c}\text { Nilai } \\
\text { Validitas } \\
\text { Tiap Aspek }\end{array}$ & $\begin{array}{c}\text { Rata-rata Total } \\
\text { Validitas (Va) }\end{array}$ \\
\hline 1 & Format & 3.85 & \multirow{2}{*}{$V a=\frac{\sum_{i=1}^{n} A i}{n}$} \\
\hline 2 & Isi & 4.2 & 4,17 \\
\hline 3 & Bahasa dan Penulisan & 3.75 & Valid \\
\hline \multicolumn{2}{|l|}{} & \\
\cline { 1 - 1 }
\end{tabular}


Pengembangan Biomagz sebagai Sumber Belajar Biologi Siswa SMA

(hlm. 132-147)

\section{Analisis Data Kepraktisan}

Adapun hasil penilaian tingkat kepraktisan oleh dua orang guru Biologi di SMAN 1 Mangkutana yang bertindak sebagai praktisi dapat dilihat pada tabel 10 berikut:

Tabel 10. Hasil Analisis Kepraktisan Biomagz

\begin{tabular}{|c|c|c|c|}
\hline No & Komponen yang ditelaah & Guru 1 & Guru 2 \\
\hline 1 & Desain sampul Biomagz menarik & 4 & 5 \\
\hline 2 & Ilustrasi gambar sesuai dengan materi & 5 & 4 \\
\hline 3 & Biomagz mudah diaplikasikan & 5 & 5 \\
\hline 4 & $\begin{array}{l}\text { Materi yang disajikan Biomagz terasa lebih } \\
\text { menyenangkan dibandingkan buku biasa }\end{array}$ & 4 & 4 \\
\hline 5 & Ukuran dan jenis huruf yang digunakan mudah dibaca & 5 & 5 \\
\hline 6 & $\begin{array}{l}\text { Kesesuaian materi dengan kompetensi dasar yang } \\
\text { termuat pada kurikulum yang berlaku }\end{array}$ & 5 & 5 \\
\hline 7 & $\begin{array}{l}\text { Isi Biomagz yang menyajikan materi yang ringan dan } \\
\text { sesuai kehidupan dimasyarakat }\end{array}$ & 4 & 5 \\
\hline 8 & Bahasa yang disajikan mudah dipahami oleh pembaca & 4 & 5 \\
\hline 9 & $\begin{array}{l}\text { Penggunaan Biomagz membantu dlam proses } \\
\text { pembelajaran karena tidak terikat ruang dan waktu } \\
\text { dikelas }\end{array}$ & 4 & 5 \\
\hline & Jumlah & 43 & 40 \\
\hline & Rata-rata tiap indikator & \multicolumn{2}{|c|}{$\underline{41,5}$} \\
\hline & $I P=\frac{\sum_{i=1}^{n} A i}{n}$ & $\underline{4,6}$ & Praktis \\
\hline
\end{tabular}

Media pembelajaran yang inovatif dan kreatif umumnya mampu meningkatkan minat belajar siswa melalui penyajian dan penyampaian materi secara menarik (Asfuriyah, 2015). Media dapat berupa audio, visual atau gabungan dari keduanya yakni audio-visual. Umumnya penggunaan media visual berbasis teks masih diminati karena lebih praktis, mudah dibawa kemana-mana tanpa memerlukan bantuan perangkat lain untuk menggunakannya. Dalam penelitian ini sendiri, peneliti ingin mengembangkan sumber belajar mandiri yang valid dan praktis yaitu majalah sains atau majalah ilmiah yang dinamakan Biomagz.

Biomagz merupakan media informasi dengan tujuan untuk menyampaikan berita aktual yang berkaitan dengan Biologi. Biomagz yang dikembangkan oleh peneliti yaitu mengenai Sistem Pencernaan yang berisi kajian utama mengenai Sitem Pencernaan yang beri nama Get Learn More. Bagian ini berisi kajian umum mengenai materi sistem pencernaan yakni saluran sistem perncernaan, kelenjar sistem pencernaan, kelainan pada sistem pencernaan, kandungan zat dalam makanan dan mekanisme pencernaan makanan pada hewan ruminansia. Selain itu terdapat pula bagian yang disebut dengan Infobio. Bagian berisi informasi pengetahuan yang terkait dengan materi sistem pencernaan yang sangat aplikatif didalam masyarakat. Biomagz merupakan media sekaligus sumber belajar bersifat interaktif karena dalam proses pembelajaran ini melibatkan antara guru dan siswa melakukan komunikasi dua arah secara aktif selama proses pembelajaran.

Pengembangan media pembelajaran Biomagz sebagai sumber belajar siswa ini mengacu pada model 4 D, yang memiliki beberapa tahapan meliputi tahapan Define (pendefenisian), design (perancangan), development (pengembangan), desiminate (penyebarluasan). Namun pada tahap yang terakhir yaitu desiminate peneliti tidak melakukannya dengan terkendala pada masalah dana yang cukup besar dibutuhkan untuk melakukan tahap ini. Dalam tahap pelaksanaan penelitian ini, banyak kendala yang dihadapi oleh peneliti seningga membuat penelitian ini tidak berjalan sempurna. Kendala yang menghambat peneliti yaitu masalah waktu validasi yang sangat 
panjang, sehingga membuat peneliti sulit untuk melakukan uji keefektifan disiswa. Kemudian kendala disaat ingin melakukan pencetakan majalah, biaya yang besar dibutuhan untuk mencetak satu majalah dan peneliti kekurangan dana untuk melakukan pencetakan. Kendala-kendala ini merupakan salah satu dari beberapa kekurangan dalam penelitian ini sehingga untuk peneliti selanjutnya supaya lebih menguasai penggunaan aplikasi software yang sering digunakan dalam mendesain majalah.

Tahap Define atau pendefenisisan yaitu tahap untuk melakukan analisis sebelum mengembangkan produk. Adapun kegiatan yang dilakukan yaitu analisis kurikulum, analisis karakteristik peserta didik, analisis materi dan merumuskan tujuan pembelajaran. Analisis kurikulum ini dilakukan agar media yang dikembangkan sesuai dengan program yang dijalankan pemerintah dan tidak melenceng dari tujuan pendidikan. Kemudian analisis karakteristik siswa, kegitan ini dilakukan dengan melakukan observasi lapangan di SMA Negeri 1 Mangkutana dengan melakukan wawancara dengan beberapa siswa dan juga guru disekolah tersebut. Analisis karakteristik siswa perlu dilakukan karena subjek dari media yang akan dikembangkan yaitu siswa dan guru. Untuk analisis materi dilkukan untuk mencari materi yang sesuai. Setlah menentukan materi yang kan dibuat dlam bentuk Biomagz, maka perlu disusun tujuan pembelajaran agar isis dari Biomagz tersusun baik sesuai dengan aturan dan kebutuhan siswa.

Pengembangan Biomagz sebagai sumber belajar mandiri siswa, berdasarkan hasil revisi dari pakar ahli terdapat beberapa yang perlu diperhatikan, mulai dari kesesuaian materi dengan produk yang akan dibuat, pemilihan software (aplikasi) yang akan digunakan, penyusunan kalimat dan bahasa yang digunakan, font tulisan, pemilihan gambar kualitas HD, serta pemilihan warna/layout desain media sangat menentukan. Pemilihan warna background dalam pembuatan majalah ini perlu diperhatikan karena turut menentukan kelayakan sebuah produk untuk menghasilkan ketertarikan terhadap suatu media sehingga menentukan kelayakan media itu sendiri. Sebagaimana yang telah dikemukakan oleh Purnama (2011), bahwa penggunaan warna yang sesuai dalam suatu produk media pembelajaran dapat membangkitkan motivasi, perasaan, perhatian, dan kesediaan siswa dalam belajar.

Tahap berikutnya setelah melakukan tahap Define yaitu mendesain, setelah didapatkan data analisis kebutuhan siswa dan penyesuaian topik pelajaran yang dibutuhkan dalam pengembangan media sumber belajar, selanjutnya merancang struktur BioMagz, yakni dari materi dan layout media. Setelah rancangan BioMagz selasai selanjutnya akan masuk ketahap Development (pengembangan).

Tahap pengembangan yaitu tahap lanjutan dari tahap desain, produk awal Biomagz yang telah dibuat kemudian divalidasi oleh validator ahli dan praktisi. Produk BioMagz sebagai sumber belajar mengalami beberapa perubahan setelah dilakukan validasi oleh validator ahli. Validasi media pembelajaran BioMagz dilakukan sebanyak 7 kali, yaitu 3 kali pada validator pertama kemudian 4 kali divalidator kedua. Selama tahap pengembangan ini berlangsung sesuai dengan evaluasi yang dilakukan oleh dosen ahli. Evaluasi yang dilakukan terhadap BioMagz berkaitan dengan layout, background, bahasa, dan kualitas gambar yang digunakan. Tak luput juga validator mengomentari konten yang layak dimasukkan kedalam Biomagz. Adapun perubahan konten yaitu, awalnya dalam Biomagz peneliti memasukkan biografi peneliti yang berkaitan, namun berdasarkan saran dari validator konten tersebut tidak sesuai dengan tujuan pembelajaran sehingga dihilangkan saja dan diganti dengan kamus Biologi. Kamus Biologi menurut validator lebih sesuai dan bermanfaat bagi siswa untuk meningkatkan kosakata biologi siswa.

Evaluasi setelah dari dosen ahli, setiapa dosen ahli melakukan validasi terhadap sumber belajar BioMagz dengan tujuan untuk mendapatkan media yang benar-benar valid menurut para ahli. Setiap dosen melakukan validasi, akan ada masukan untuk setiap perbaikan BioMagz. Hal ini sesuai denagn pendapat Asfuriyah (2015) yang mengatkan bahwa perbaikan berdasarkan validator bertujuan untuk melengkapi kekurangan dari BioMagz. Setelah sumber belajar BioMagz sudah sesuai penilaian validator, maka BioMagz akan dinilai oleh para guru dan siswa sebagai subjek dalam penelitian ini. Evaluasi kemudian dilakukan kesekolah dengan meminta 
bantuan praktisi lapangan yaitu guru biologi dan siswa evaluasi disekolah bertujuan untuk mengukur kepraktisan BioMagz. kepraktisan ini bertujuan untuk mengetahu apkan BioMagz layak untuk dijadikan sumber belajar di SMA Negeri 1 Mangkutana. Berdasarkan kegitan evaluasi disekolah maka didaptkan data bahwa Biomagz dinyatakan praktis dan dapat digunakan.

1. Kevalidan Media Pembelajaran BioMagz

Sumber belajar BioMagz dapat digunakan dalam proses pembelajaran, setelah melewati tahap validasi. Uji kevalidan sumber belajar ini bertujuan untuk melihat kekurangan media yang dikembangkan yang selanjutnya diikuti tahap perbaikan sampai BioMagz dianggap layak untuk digunakan. Menurut Arikunto (2010) bahwa validitas adalah tingkat kevalidan suatu instrument. Instrument yang valid adalah instrument yang mampu mengukur apa yang harus diukur.

Validasi media pembelajaran dilakukan oleh validator dari jurusan biologi FMIPA UNM, hasil validasi media pembelajaran bertujuan untuk menilai kelayakan dari media yang dikembangkan, pernyataan dalam lembar validasi terdiri dari 19 pernyataan, yang terdiri dari 3 aspek penilaian kevalidan secara garis besar yaitu format desain BioMagz, isi BioMagz, dan bahasa dalam BioMagz.

Setelah melakukan perbaikan sesuai saran tersebut produk Biomagz dinyatakan dapat digunakan. Berdasarkan analisis data penilaian ahli dan praktisi sebagaimana telah diuraikan pada penyajian halaman validasi, secara umum BioMagz yang dikembangkan telah memenuhi kriteria kevalidan. Adapun criteria kevalidan yang telah dipenuhi yaitu berdasarkan aspek format tampilan, aspek isi dan aspek bahasa yang digunakan dalam BioMagz. Dalam hal ini dapat dijelaskan bahwa BioMagz yang telah dikembangkan telah didasari pada kajian teoritik yang kuat serta memiliki konsistensi secara internal. Interpretasi ini didasarkan pda perolehan data validitas Biomagz yang divalidasi berada pada interval $3 \leq \mathrm{VR}<4$, dalam kategori valid yaitu 4,17 .

\section{a. Aspek Format Tampilan Biomagz}

Aspek ini terdiri dari sub-aspek (1) ukuran huruf pada sumber belajar Biomagz, (2) variasi jenis huruf pada sumber belajar Biomagz, (3) keterbacaan teks pada sumber belajar (4) Kualitas gambar pada sumber belajar Biomagz, (5) Keserasian pemilihan warna background dengan teks dan gambar, (6) ketepatan penempaytan gambar pada sumber belajar Biomagz, (7) ketepatan layout pengetikan sumber belajar Biomagz, (8) ketepatan penempatan judul dan subjudul pada Biomagz, (9) kesesuaian pengorganisasian isi Biomagz.

Penilaian terhadap desain BioMagz dinyatakan valid dengan nilai 4,1. Font tulisan dan background penulisan harus diperhtikan agar BioMagz dapat digunakan dengan nyaman oleh siswa sebagaimana yang dijelaskan oleh Agustin (2014) yang menjelaskan bahwa majalah BioMagz tipografi yang digunakan harus memenuhi aspek legibility (kemudahan dalam mengenali dan membedakan masing-masing huruf atau karakter) dan readability (keterbacaan suatu teks), sehingga hal itu membuat penyaji buku dan anak-anak memiliki kenyamanan membaca semaksimal mungkin.

Penilaian terhadap desain BioMagz dinyatakan valid dengan nilai 4,1. Font tulisan dan background penulisan harus diperhatikan agar BioMagz dapat digunakan dengan nyaman oleh siswa sebagaimana yang dijelaskan oleh Agustin (2014) yang menjelaskan bahwa majalah BioMagz tipografi yang digunakan harus memenuhi aspek legibility (kemudahan dalam mengenali dan membedakan masing-masing huruf atau karakter) dan readability (keterbacaan suatu teks), sehingga hal itu membuat penyaji buku dan anak-anak memiliki kenyamanan membaca semaksimal mungkin.

Pengunaan BioMagz dapat dicetak dalam bentuk buku maupun dalam bentuk PDF. Dari segi desain cover majalah dibuat rapi dan bersih sesuai saran validator hal ini ditujukan agar sampul menarik dan mudah dibaca. Hasil cetakanpun terlihat bersih dan kontras sehingga mudah dibaca hal tersebut didukung oleh Kurniawati (2015) dalam Efendi (1986) penggunaan warna yang berbeda dalam rangka menarik perhatian dan keterbacaan. Majalah juga dilengkapi dengan daftar isi sehingga mempermudah pembaca dalam mencari topik yang ingin dibaca. 


\section{b. $\quad$ Aspek isi Materi Biomagz}

Aspek isi materi Biomagz terdiri atas sub-aspek (1) kesesuaian materi (sistem pencernaan dengan standar kompetensi, (2) kebenaran materi (sistem pencernaan) yang disajikan, (3) penyajian materi (sistem pencernaan) secara berurutan dan sitematik, (4) kejelasan uraian materi sistem pencernaan, (5) kesesuaian gambar yang disajiakan pada materi maupun sub materi.

Hasil penilaian terhadap isi BioMagz dinyatakan valid dengan nilai 4,2. Kevalidan isi BioMagz telah dijelaskan oleh Agustin (2014) yang menjelaskan bahwa ilustrasi gambar yang digunakan pada media harus menarik dan sesuai dengan materi yang dipilih. Namun dalam BioMagz ada beberapa ilustrasi gambar yang harus diperbaiki penunjukannya agak siswa tidak salah dalam menerima informasi dari BioMagz. Isi BioMagz sudah memenuhi salah satu prinsip kesatuan (unity). Berdasarkan penelitian, secara keseluruhan layout dari setiap elemenelemen di dalam buku tidak ada masalah dalam pengaturannya sehingga kesatuan dan keselarasan antara elemen-elemen yang terlihat secara fisik dengan pesan yang ingin disampaikan sudah memenuhi prinsip kesatuan.

c. Aspek Bahasa Biomagz

Aspek bahasa didalam Biomagz terdiri dari beberapa su-aspek (1) Kesesuaian bahasa dengan tingkat berpikir siswa, (2) kelugasan bahasa pada Biomagz, (3) ketepatan penggunaan istilah, tata bahasa, dan ejaan yang digunakan, (4) bahasa yang digunakan membangkitkan rasa ingin tahu siswa.

Skor rara-rata dari aspek bahasa yaitu 3,75 yang diartikan cukup valid. Dilihat darisegi kebahasaan, BioMagz dikembangkan dengan menggunakan bahasa Indonesia dengan berpedoman pada EYD dan menggunakan bahasa yang dialogis serta komunikatif. Hal ini juga dijelaskan oleh Kurniawati (2015) yang menjelaskan bahwa pengunaan bahasa atau kata-kata atau peristilahan yang digunakan harus berpatokan pada topik yang sesuai dan mengunakan bahasa yang mudah dipahami dan dibaca oleh siswa.

Validitas Biomagz berbasis masalah diuji pada tahap pengembengan Biomagz berlangsung. Tahap pengembangan Biomagz dilakukan sesuai dengan tahap desain yang telah dibuat peneliti. Validasi Biomagz dilakukan oleh 2 orang validator ahli dengan cara melihat dan menilai langsung Biomagz yang telah dibuat, kemudian memberikan nilai pada lembar validasi.

Berdasarkan hasil analisis datakevalidan Biomagz diperoleh nilai kevalidan dari dua validator ahli untuk setiap aspek penilaian yaitu format tampilan Biomagz adalah 4,1, kesesuaian isi materi Biomagz adalah 4,2, bahasa yang digunakan dalam Biomagz adalah 3,75. Jadi nilai ratarata kevalidan Biomagz adalah 4,17 sehingga dapat disimpulkan bahwa nilai ini termasuk dalam kategoria "Valid" $(4 \leq \mathrm{V}<5)$

Kevalidan Biomagz disimpulkan dalam kategori valid karena Biomagz yang telah dikembangkan memenuhi semua aspek kevalidan yaitu aspek format tampilan, kesesuaian isi materi, dan kesesuaian bahasa. Berdasarkan nilai total kevalidan Biomagz, maka Biomagz ini layak untuk digunakan dengan revisi besar di SMA Negeri 1 Mangkutana Kabupaten Luwu Timur. BioMagz adaalah salah satu media alternaif sebagai sumber belajar mandiri siswa yang valid, hal ini juga telah dibuktikan melalui penelitian yang dilakukan oleh Asfuriyah (2015) yang mengatakan bahwa Majalah BioMagz dapat dinyatakan layak sesuai aspek BSNP yang menyatakan bahwa majalah BioMagz dikatakan "Layak," jika memenuhi aspek kelayakan isi, aspek kebahasaan, penyajian, dan kegrafikan

Kevalidan Biomagz penting untuk diuji sebab kevalidan merupakan salah satu kriteria yang menentukan suatu produk pengembangan dikatakan baik dan layak guna. Adapun standar valid yang digunakan yaitu dengan berdasarkan hasil penilaian dari dosen validator yang sesuai untuk menilai BioMagz baik dari segi format tampilan maupun isi majalah.

\section{Kepraktisan Biomagz}

Kepraktisan sumber belajar BioMagz dapat dilihat respon guru dan respon siswa, berdasarkan penelitian tentang respon guru dan respon siswa terhadap sumber belajar yang telah dilakukan, maka ada beberapa kriteria pada instrumen yang diberikan pada respon guru 
dan siswa, respon siswa terdiri dari kriteria, kemanfaatan media, tampilan, interaksi, belajar mandiri Keempat aspek tersebut kemudian dijabarkan kedalam 15 pertanyaan dalam instrumen yang terdiri dari pernyataan positif dan pernyataan negatif. Sedangkan aspek penilaian terhadap guru yaitu berisisi 9 penilaian terhadap BioMgz.

Untuk melihat respon siswa maka dilakukan Ujicoba kelompok kecil dilaksanakan di SMA Negeri 1 Mangkutana dengan jumlah subjek sebanyak 10 orang siswa. Tujuan dilakukannya ujicoba kelompok kecil untuk melihat respon siswa terhadap produk yang telah dikembangkan. Media majalah memiliki ciri khas tersendiri dengan menghadirkan lebih banyak variasi gambar dan informasi yang menarik sehingga dapat mendorong minat belajar siswa. Selanjutnya menurut Asyhar (2010) bahwa majalah sebagai media pembelajaran dapat menambah kemenarikan tampilan materi pembelajaran sehingga dapat memotivasi belajar siswa dan efektivitas siswa dalam belajar. Dengan menggunakan media pembelajaran dapat mempercepat tercapainya tujuan pembelajaran dan meningkatkan hasil belajar siswa karena adanya motivasi untuk belajar. Hal ini juga diperkuat dengan pernyataan Susilana (2011) salah satu fungsi media pembelajaran untuk mempercepat proses pembelajaran. Siswa dapat menangkap tujuan dan bahan ajar lebih mudah dan lebih cepat. Hasil belajar siswa akan tahan lama mengendap sehingga kualitas pembelajaran memiliki nilai yang Berdasarkan hasil analisis uji respon siswa yang telah dilakukan, diperoleh rata-rata persentase untuk respon siswa yakni 84,5\% dengan keterangan $70 \% \leq \mathrm{RS}<85 \%$ nilai berada pada kategori "positif" berdasarkan kategori respon siswa. Komponen Desain sampul Biomagz menarik. Sedangkan hasil penilaian guru terhadap BioMagz yaitu sangat "sangat praktis" dengan nilai 4,6 .

Berdasarkan hasil penelitian kepraktisan pada komponen desain sampul Biomagz maka diperoleh skor rata-rata dari kedau praktisi adalah 4,5. Hal ini mengindikasikan bahwa Biomagz yang telah dikembangkan memiliki desian yang menarik sehingga menjadi salah satu faktor yang dapat memberikan motivasi kepada siswa untuk melakukan kegiatan membaca atau belajar mandiri. Dari segi tampilan, BioMagz dikembangkan dengan full color. Hal tersebut membuat BioMagz menjadi bebrbeda dengan buku ataupun LKS yang sering digunakan siswa. Hal ini juga sesuai dengan hasil penelitian dari Kurniawati (2015) yang memperjelaskan bahwa desain majalah yang full color membuat siswa tidak mudah bosan saat membaca. Tampilan majalah yang berwarna juga akan lebih banyak meninggalkan kesan bagi siswa, hal ini dijelaskan oleh Agustin (2014) yang menjelaskan bahwa Penggunaan warna-warna pada buku sesuai dengan anak-anak karena mereka menyenangi warna yang muda, terang, ceria, dan colorfull . Namun, pemilihan warna harus disesuaikan dengan minat penampilan anak laki-laki yang ingin tampak maskulin dan perempuan yang ingin tampak feminism. Komponen Ilustrasi gambar sesuai dengan materi.

Berdasarkan hasil penelitian kepraktisan pada komponen Ilustrasi gambar sesuai dengan materi maka diperoleh skor rata-rata dari kedau praktisi adalah 4,5. Hal ini mengindikasikan bahwa Biomagz yang telah dikembangkan memliki Ilustrasi gambar sesuai dengan materi sehingga menjadi salah satu faktor yang dapat memberikan motivasi kepada siswa untuk melakukan kegiatan membaca ataupun belajar mandiri. BioMagz juga dilengkapi dengan gambargambar yang menarik beserta sumbernya sehingga siswa dapat mengaksesnya secara langsung di internet. Hal tersebut didukung oleh Kurniawati (2015) dalam Mohammad (2007) yang menjelaskan bahwa modul sebaiknya memasukkan beragam bantuan belajar dan gambar (gambar, aktivitas, eksperimen) serta penjelasan yang tepat mengenai topik untuk pemahaman konsep.

Komponen Biomagz mudah digunakan ataupun diaplikasikan. Berdasarkan hasil penelitian kepraktisan pada komponen Biomagz yang mudah digunakan maka diperoleh skor rata-rata dari kedua praktisi adalah 5. Hal ini mengindikasikan bahwa Biomagz yang telah dikembangkan mudah digunakan dan tidak menyusahkan sehingga menjadi salah satu faktor yang dapat memberikan motivasi kepada siswa untuk sering membaca Biomagz.

Komponen materi yang disajikan Biomagz lebih menyenangkan dibandingkan buku biasa. Berdasarkan hasil penelitian kepraktisan pada komponen Biomagz disajikan lebih menyenangkan dibandingkan buku biasa diperoleh skor rata-rata dari kedau praktisi adalah 4 . 
Hal ini mengindikasikan bahwa Biomagz yang telah dikembangkan menyediakan materi yang menyenangkan dari buku biasa sehingga menjadi salah satu faktor yang dapat memberikan motivasi kepada siswa untuk membaca Biomagz dan belajar mandiri. Penjelasan mengenai motivasi belajar siswa saat menggunakan majalah juga dijelaskan oleh Rangsing (2015) yang menjelaskan bahwa majalah dalam pembelajaran dapat meningkatkan motivasi belajar. Siswa setelah menggunakan Bahan Ajar Fisika Berbasis Majalah Siswa Pintar Fisika (MSPF) Pada Pembelajaran IPA di SMP (Pokok Bahasan Gerak pada Benda) dikategorikan termotivasi dengan rata-rata nilai sebesar $80,4 \%$,).

Komponen Ukuran dan jenis huruf yang digunakan mudah dibaca. Berdasarkan hasil penelitian kepraktisan pada komponen Ukuran dan jenis huruf yang digunakan mudah dibaca maka diperoleh skor rata-rata dari kedau praktisi adalah 5. Hal ini mengindikasikan bahwa Biomagz yang telah dikembangkan memiliki Ukuran dan jenis huruf yang digunakan mudah dibaca sehingga menjadi salah satu factor yang dapat memberikan motivasi kepada siswa untuk melakukan membaca Biomagz dan belajar mandiri.

Komponen kesesuaian materi dengan kompetensi dasar yang termuat dalam kurikulum yang berlaku. Berdasarkan hasil penelitian kepraktisan pada komponen kesesuaian materi dengan kompetensi dasar yang termuat dalam kurikulum yang maka diperoleh skor rata-rata dari kedau praktisi adalah 5. Hal ini mengindikasikan bahwa Biomagz yang telah dikembangkan memiliki materi yang sesuai dengan kebutuhan siswa disekolah sehingga menjadi salah satu faktor yang dapat memberikan motivasi kepada siswa untuk membaca dan belajar mandiri.

Komponen isi Biomagz yang menyajikan materi yang ringan dan sesuai kehidupan dimasyarakat. Berdasarkan hasil penelitian kepraktisan pada komponen isi Biomagz yang menyajikan materi yang ringan dan sesuai kehidupan dimasyarakat dari kegiatan praktikum maka diperoleh skor rata-rata dari kedau praktisi adalah 4,5. Hal ini mengindikasikan bahwa Biomagz yang telah dikembangkan memiliki Penyajian materi yang tidak memberatkan bagi siswa maupun guru sehingga menjadi salah satu factor yang dapat memberikan motivasi kepada siswa membaca.

Komponen Bahasa yang disajikan mudah dipahami oleh pembaca. Berdasarkan hasil penelitian kepraktisan pada komponen bahasa yang disajikan mudah dipahami oleh pembaca maka diperoleh skor rata-rata dari kedau praktisi adalah 4,5. Hal ini mengindikasikan bahwa Biomagz yang telah dikembangkan memiliki Penyajian materi dengan bahasa yang mudah untuk dipahami oleh pembaca sehingga menjadi salah satu faktor yang dapat meningkatkan minat baca dan pemahaman siswa terhadap bahan bacaan dalam Biomagz. Komponen bahasa memang selalu menjadi poin penilaian karena bahasa sangat menentukan pemahaman siswa. Hal ini juga dijelaskan oleh Kurniawati (2015) yang menjelaskan bahwa pengunaan bahasa atau kata-kata atau peristilahan yang digunakan harus berpatokan pada topik yang sesuai dan mengunakan bahasa yang mudah dipahami dan dibaca oleh siswa.

Komponen penggunaan Biomagz membantu dalam proses pembelajaran karena tidak terikat ruang dan waktu. Berdasarkan hasil penelitian kepraktisan pada komponen penggunaan Biomagz yang dimana dan kapanpun maka diperoleh skor rata-rata dari kedau praktisi adalah 4,5. Hal ini mengindikasikan bahwa Biomagz sangat tepat sebagai sumber belajar mandiri siswa saat sedang tidak dikelas, sehingga menjadi salah satu faktor yang dapat memberikan motivasi kepada siswa untuk banyak membaca. Dengan adanya motivasi membaca maka dihrapkan siswa dengan cepat menguasai suatu kompetensi yang ingin dicapai dalam suatu pembelajaran.

Kepraktisan Biomagz disimpulkan termasuk dalam kategori sangat praktis karena Biomagz yang telah dibuat memenuhi aspek kepraktisan berdasarkan hasil analisis respon guru yang menunjukkan hasil positif dengan kategori setuju. Berdasarkan nilai total kepraktisan Biomagz maka Biomagz dinyatakan praktis dan layak digunakaan di SMA Negeri 1 Mangkutana. Menurut Prastowo (2011), menyatakan kepraktisan dari suatu bahan ajar hanya dapat dipenuhi jika para ahli dan praktisi menyatakan bahwa apa yang dikembangkan dapat diterapkan. Kepraktisan Biomagz sebagai sumber belajar mandiri dilihat dari hasil respon guru. Kepraktisan Biomagz penting untuk diuji sebab kepraktisan merupakan salah satu kriteria yang menentukan sebuah 
produk pengembangan dikatakan baik dan layak guna, namun peneliti tidak berkesempatan untuk melanjutkan untuk diuji cobakan kepada siswa karena keterbatasan dana. Dan sangat diharapkan jika ada peneliti yang ingin melanjutkan penelitian ini ketahap yang lebih lanjut apakah itu melalui penelitian eksperimen ataupun PTK.

\section{Kesimpulan}

Berdasarkan hasil penelitian bahwa produk BioMagz sebagai alternative sumber belajar mandiri yang valid dan praktis digunakan di SMA Negeri 1 Mangkutana. Nilai kevalidan adalah 4,17 yang berarti bahwa BioMagz sebagai alternatif sumber belajar mandiri termasuk dalam kriteria valid. Nilai kepraktisan adalah 4,6 yang berarti bahwa BioMagz sebagai alternatif sumber belajar mandiri tergolong dalam kriteria praktis. Persentasi Hasil respons siswa terhadap siswa yaitu 84,5\% yang berarti siswa memberikan respon positif terhadap BioMagz.

\section{Referensi}

Agustin, R dan Erdi, I dan Dewi, R. (2014). Kelayakan Buku Pop-Up sebagai alternatif Media Pendidikan Kesehatan Reproduksi. E-Jurnal Pustaka Kesehatan. 2 (2).

Akhmad, R dan Abu A. (1995). Pengelolahan Pengajaran. Jakarta. PT Rineka Cipta.

Ali, M. (2009). Pengembangan Media Pembelajaran Interaktif Mata Kuliah Media Elektromagnetik. Jurnal Edukasi. 5 (1).

Aritonang, K. T. (2008). Minat dan Motivasi dalam Meningkatkan Hasil Belajar Siswa. Jurnal Pendidikan Penabur, 10 (7).

Asfuriya, S dan Murbangun N. (2015). Pengembangan Majalah SAINS Berbasis Contextual Learning pada Tema Pemansan Global Untuk Meningkatkan Minat Belajar Siswa. Unnes Science Education Journal. 4 (1).

Darwis, Muhammad. (2007). Model Pembelajaran Matematik yang Melibatkan Kecerdasan Emosional. Disertasi Pasca Sarjana Program Studi Pendidikan Matematika. Universitas Negeri Surabaya.

Hobri. (2009). Metodologi Penelitian Pengembangan (Developmental Research) (Aplikasi pada Penelitian Pendidikan Matematika). Jember. FKIP Universitas Jember.

Kurniawati, Eka. (2015). Pengembangan Majalah Biosmart Invertebrata untuk meningkatkan Aktivitas dan Hasil Belajar Siswa SMA. Skripsi. Universitas Negeri Semarang.

Rangsing, B dan Subiki dan Rif'ati, D.H. (2015). Pengembangan Bahan Ajar Fisika Berbasis Majalah Siswa Pintar Fisika (MSPF) Pada Pembelajaran IPA di SMP. Jurnal Pembelajaran Fisika. 4 (3)

Rahmayani, A. (2015). Pengembangan media Open Office untuk meningkatkan Hasil belajar siswa kelas XI SMA. Proposal Penelitian. Makassar. FMIPA. Universitas Negeri Makassar.

Riyani, D. (2013). Pengembangan Majalah Biomagz Sebagai Alternatif Sumber Belajar Mandiri pada Mata Pelajaran Biologi untuk Siswa SMA/MA Kelas X. Jurnal Teknologi Pendidikan. 10 (2). 
Sudijono, Anas. (2009). Pengantar Evaluasi Pendidikan. Jakarta. PT Raja Grafindo Persada.

Sugiyono. (2014). Metode Penelitian Pendidikan. Bandung. Alfabeta.

Trianto. (2010). Model Pengembangan Terpadu: Konsep, Strategi dan Implementasi dalam KTSP. Jakarta. Bumi Aksara.

Trianto. (2014). Model pengembangan Terpadu dan implementasinya dalam kurikulm Tingkat Satuan Pendidikan. Jakarta. Bumi Aksara.

Yulianto, Eko. (2010). Pengembangan Majalah Kimia Sebagai Alternatif Sumber Belajar Mandiri pada Mata Pelajaran Kimia Untuk Peserta Didik SMA/MA Kelas X. Skripsi. Universitas Negeri Yogyakarta.

\begin{tabular}{|l|l|}
\hline Gregorian Trijulensius & $\begin{array}{l}\text { Mahasiswa Jurusan Biologi, Fakultas Matematika dan Ilmu } \\
\text { Pengetahuan Alam, Universitas Negeri Makassar } \\
\text { E-mail: gregorianogi@gmail.com }\end{array}$ \\
\hline Mushawwir Taiyeb & $\begin{array}{l}\text { M.Kes, Dr. Dosen Jurusan Biologi, Fakultas Matematika dan Ilmu } \\
\text { Pengetahuan Alam, Universitas Negeri Makassar } \\
\text { E-mail: } \underline{\text { mtaiyeb333@gmail.com }}\end{array}$ \\
\hline Andi Asmawati Azis & $\begin{array}{l}\text { M.Si, Dr. Dosen Jurusan Biologi, Fakultas Matematika dan Ilmu } \\
\text { Pengetahuan Alam, Universitas Negeri Makassar } \\
\text { E-mail: asma.azis@gmail.com }\end{array}$ \\
\hline
\end{tabular}

